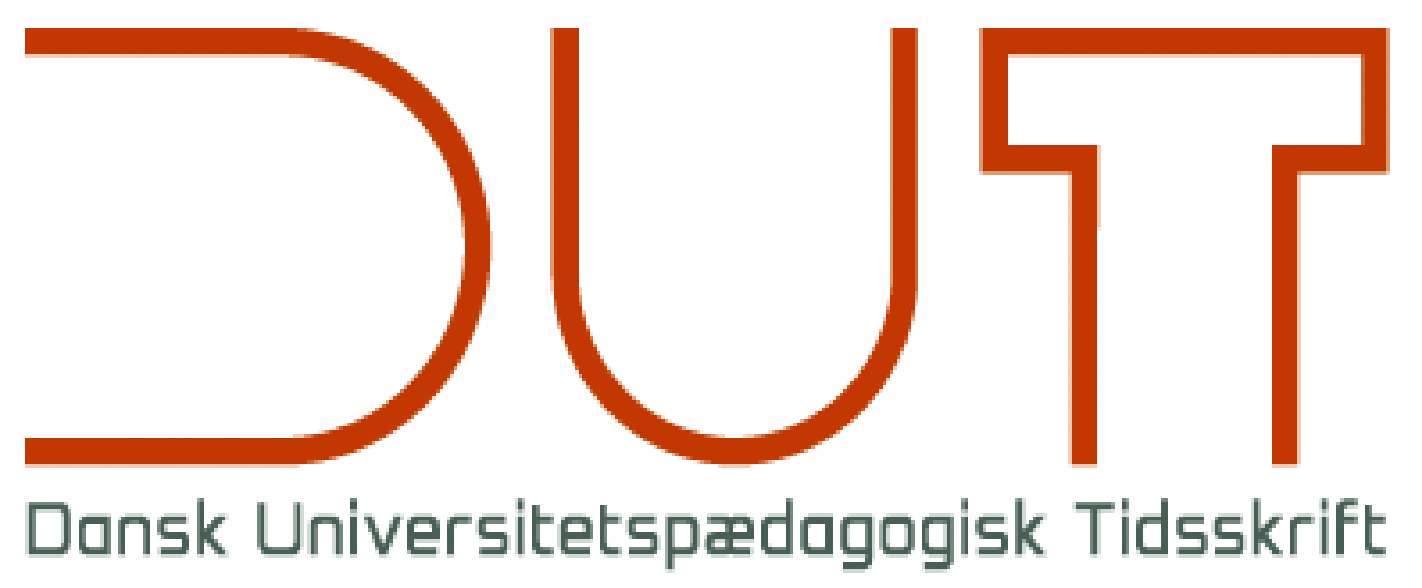

Læringsrum

Årgang 14 nr. 27 / 2019

Titel

Learning Analytics og udvikling af studerendes autonomi og autenticitet

Forfattere

Sidetal

Frederik Voetmann Christiansen, Helle Mathiasen, Mikkel Willum Johansen

$35-49$

Udgivet af

Dansk Universitetspædagogisk Netværk, DUN

URL

> http://dun-net.dk/

Betingelser for brug af denne artikel

두 Copyright
Denne artikel er omfattet af ophavsretsloven, og der må citeres fra den. Følgende betingelser skal dog være opfyldt:

- Citatet skal være i overensstemmelse med "god skik"

- Der må kun citeres „i det omfang, som betinges af formålet“

- Ophavsmanden til teksten skal krediteres, og kilden skal angives ift. ovenstående bibliografiske oplysninger.

DUT og artiklens forfatter 


\title{
Learning Analytics og udvikling af studerendes autonomi og autenticitet
}

\author{
Frederik Voetmann Christiansen ${ }^{\mathrm{a}, 1}$, Helle Mathiasen ${ }^{\mathrm{a}}$, Mikkel Willum Johansen ${ }^{\mathrm{a}}$ \\ anstitut for Naturfagenes Didaktik, Københavns Universitet
}

Videnskabelig artikel, fagfællebedømt

\begin{abstract}
Et læringsmiljø på universitetet, der i stigende grad præges af registrering, kontrol og vurdering, giver udfordringer i forhold til de studerendes autonomi. Autonomi er ikke kun et spørgsmål om privatliv, men også om den akademiske frihed, der har været et centralt mål for universitetsuddannelserne siden dannelsen af det forskningsbaserede universitet. Vi stiller spørgsmålet: Hvordan kan universitetsundervisere tilrettelægge undervisningen på måder, som samtidig bevarer de studerendes autonomi og autenticitet i studieadfærden? Med afsæt i bogen "Freedom to learn" (Macfarlane 2017) drøfter vi, hvordan vi som undervisere kan give studerende mulighed for at udfolde autonomi og autenticitet og giver eksempler på faldgruber i design af undervisningsforløb, som anvendelsen af learning analytics, i større eller mindre skala, kan føre til. Et særligt fokus er på brugen af learning analytics til kontrol af adfærd gennem summative evalueringer.
\end{abstract}

\section{Introduktion}

Undervisningsinstitutioner og undervisere tager mange beslutninger om deres studerende, lige fra beslutninger om, hvem de ønsker at optage til beslutninger om undervisningsdesign og om allokering af karriere- og studievejledningsresurser. Disse beslutningerne er baseret på data, og med digitaliseringen og den øgede anvendelse af learning analytics er der mulighed for, at beslutningerne kan blive taget på et mere informeret grundlag.

Det står dog også klart, at brugen af learning analytics er forbundet med en række etiske, epistemologiske og didaktiske udfordringer. Indsamling og brug af store mængder personhenførbare data rejser åbenlyse udfordringer i forhold til ønsket om og retten til at opretholde individets integritet og private sfære. Brugen af algoritmer til forudsigelse af studerendes adfærd rummer desuden en latent fare for algoritmisk bias og profilering (Angwin et al. 2016, se også Mittelstadt \& Floridi 2016).

I denne artikel vil vi fokusere på de studerendes muligheder for at udfolde autonomi og autenticitet og undersøge hvilke opmærksomhedspunkter, universitetsunderviseren må have i forhold til anvendelsen af learning analytics i både stor og mindre skala, specielt når denne anvendes til (summativ) bedømmelse af de studerende.

Learning analytics er ikke blot et nyt væsentligt forskningsområde: det er også allerede en virkelighed, undervisere og studerende konfronteres med i deres daglige arbejde. Det sker f.eks. gennem undervisningsplatformen (LMS), der holder styr på afleveringer og aktivitet,

\footnotetext{
${ }^{1}$ Kontakt: fchristiansen@ind.ku.dk
} 
opdager plagiat, tilordner studerende til grupper og så videre. At kunne forholde sig hensigtsmæssigt til anvendelsen af maskinelt indsamlede data om de studerende bliver således en stadig større del af undervisningsopgaven, og det er diskussionen af, hvad vi som undervisere skal være opmærksomme på i den forbindelse, vi gerne vil bidrage til med denne artikel.

Udover at tage udgangspunkt i den enkelte underviser og dennes muligheder i forhold til brug af learning analytics, vil vi desuden skærpe fokus ved at se på learning analytics' betydning for de studerendes autonomi, der - som vi vil forklare yderligere nedenfor - udgør et væsentligt element i en akademiske dannelse. I begrebet akademisk dannelse indgår også en autenticitetsdimension, som indeholder personlige, etiske og eksistentielle aspekter, herunder f.eks. ærlighed og troværdighed (se nærmere udfoldning af begrebet i Solberg \& Hansen, 2015). Vores overordnede spørgsmål er dermed:

Hvordan kan undervisere på landets universiteter fastholde og bidrage til at udvikle studerendes autonomi og autenticitet $i$ en uddannelsesmaessig virkelighed, hvor monitorering, kontrol og bedømmelse spiller en stadig større rolle?

Udgangspunktet for det argument, vi vil udfolde, er, at udviklingen af videnskabeligt funderede og selvstændigt tænkende kandidater er universitetets væsentligste opgave. Vi vil argumentere for, at brugen af learning analytics og summativ bedømmelse rummer faldgruber, der kan true denne udvikling. Vi vil derfor i den første del af artiklen udfolde argumenter for, at målet om udvikling af de studerendes autonomi måske ikke har fået tilstrækkelig opmærksomhed, og herefter drøfte, hvordan vi som universitetsundervisere kan forholde os til anvendelsen af learning analytics i tilrettelæggelsen af undervisningsmiljøer.

\section{Udvikling af de studerendes autonomi}

Det danske universitetssystem er på afgørende punkter inspireret af den vision for et nyt forskningsbaseret universitet, der blev formuleret af Wilhelm von Humboldt i begyndelsen af 1800-tallet, og som viste sit værd op gennem det 19. og det 20. århundrede. Beskrivelsen af hovedopgaverne for universitetet som bestående af forskning og forskningsbaseret uddannelse til højeste niveau (Universitetslovens §2), grundfinansieringen med en samlet basisbevilling til indfrielse af formålene og en stillingsstruktur, der specificerer, at de fastansatte involveres i både forskning og undervisning, er alle tegn på, at arven fra Humboldt - trods justeringer - fortsat er tilstede i det danske universitetssystem. Værdien af akademisk frihed fremhæves også jævnligt i den danske debat - f.eks. i forhold til institutlederes instruktionsbeføjelser og universiteternes myndighedsbetjening. Ofte forbindes akademisk frihed alene med de ansattes forsknings- og undervisningsfrihed (Lehrfreiheit), men i det Humboldske universitet var/er dette kun den ene side af medaljen - den anden er de studerendes lærefrihed (Lernfreiheit) (Kjærgaard \& Kristensen, 2003). Det forhold, at den akademiske frihed også indbefatter de studerende, ser vi som en væsentlig pointe. For Humboldt var de to principper afgørende: Universitetet kan ikke nå sin målsætning om uddannelse af kritisk tænkende individer, uden at begge principper fastholdes (Humboldt, 1810). Det centrale mål i Humboldts reformation af universitetsvæsenet var uddannelsen af kritisk tænkende individer, der kunne bidrage med videnskabeligt funderede løsninger på måder, som man fra statens side ikke havde fantasi til at udvikle og implementere. Afgørende for denne tanke var derfor, at der ikke skulle gives centralt fastsatte læreplaner for universitetsundervisningen - underviserne måtte være selvstændigt tænkende og gives frihed i undervisningstilrettelæggelsen. Dette princip kommer stadig til udtryk på de danske universiteter, bl.a. i den praksis, at kursusbe- 
skrivelser udarbejdes af de ansvarlige undervisere. De studerende skulle på deres side også gives udstrakt grad af frihed til at forfølge deres egne idéer, og bruge deres tid på netop det, som de fandt relevant. Hermann von Helmholtz udtrykte dette radikalt i sin tiltrædelsesforelæsning til de studerende, da han tiltrådte som rektor ved Universitetet i Berlin:

Mine herrer i studenterforeningen, De ser, hvordan nationen her igen udviser Dem en arefuld tillid. Man foreskriver Dem ikke bestemte kurser og bestemte undervisere. Man betragter Dem som moend, hvis frie overbevisning skal vindes; moend, der vil kunne adskille essensen fra skinnet; maend, som man ikke kan berolige under henvisning til en eller anden autoritet, og maend, der i det hele taget ikke mere bør lade sig berolige. Og tillige er der altid sørget bedst muligt for, at De selv kan gå til videns kilder, hvad end dette sker ved hjoelp af bøger og mindesmaerker eller ved hjoelp of forsøg og observationer af naturlige objekter. (Helmholtz, 1877, s. 127)

Om de studerende fik udvist så ubetinget tillid, som citatet antyder, kan sikkert anfægtes men vi kan konstatere, at det politiske system ikke i dag udviser den grad af tiltro til vores studerende. Det Humboldske universitet var ikke blot radikalt i tiltroen til forskningen og videnskaben, men også i tiltroen til de studerendes rationalitet. Udviklingen af de studerende til akademisk dannede borgere var den centrale målsætning for universitet, og akademisk frihed var centralt for både forskere og studerende.

I debatten om udviklingen af universitetsuddannelserne i Danmark er det også klart, at udviklingen af de studerendes autonomi fortsat ses som et af de væsentligste mål, men også at der er en oplevelse af, at de studerendes autonomi er under pres fra flere sider. F.eks. er der den aktuelle debat om 7-trinsskalaen og afskaffelsen af karakteren 13; hvor 13-tallet blev givet for en "usædvanlig selvstændig og udmærket præstation" bliver 12-tallet givet for den "fremragende præstation, der demonstrerer en udtømmende opfyldelse af fagets, fag- eller uddannelseselementets mål, med ingen eller få uvæsentlige mangler" (se f.eks. Lund \& Pedersen, 2015; Ejsing, 2016). Kritikken er, at målsætningen må være at uddanne kandidater, der kan "tænke ud af boksen" og ikke blot "opfylder mål". Også fremdriftsreformens målsætning om at nedbringe den samlede studietid angives at have indskrænket de studerendes mulighed for at prøve deres valgfrihed af og for at træffe selvstændige, autonome beslutninger om sammensætningen af deres uddannelse (Hjortdal, 2015, Abrahamsen, 2017). Begge disse tiltag er blevet mødt af en vis kritik i den offentlige debat, og specielt fremdriftsreformen har vakt udbredt bekymring blandt både studerende og universitetsansatte $\mathrm{i}$ forhold til at true de studerendes autonomi (Elling \& Groes 2015).

Behovet for en (gen)etablering af de studerendes selvstændighed og personlige dømmekraft bakkes op i den rapport, den såkaldte inspirationsgruppe om nyt filosofikum udarbejdede i juni 2018 (Eika et al, 2018). I rapporten argumenteres der for, at der skal etableres et nyt studieelement i alle danske universitetsuddannelser (med samlet omfang på 15 ECTS), som skal bidrage til den akademiske dannelse af studerende. Kursuselementet skal bære navnet "Akademia", og skal bidrage til at "udvikle den universitetsstuderende som fagperson, menneske og borger ved at fremme nysgerrighed, kritisk tænkning og dømmekraft" (Eika et al, 2018, s. 6). Begrundelsen for det fornyede behov for fokus på den akademiske dannelse angives at være bl.a. den teknologiske udvikling og demokratiske udfordringer, men det står også klart fra udvalgets rapport, at tanken om akademisk dannelse ikke er ny, og at der er tale om, at allerede etablerede værdier og mål skal tydeliggøres. 


\section{Interne trusler mod studerendes autonomi}

Fremdriftsreformen, ændringen af karakterskalaen (og en række lignende tiltag) er alle foranstaltet gennem lovgivning, men det er ikke alene tiltag initieret fra politisk hold, der kan opfattes som trusler i forhold til de studerende selvstændighed. Den engelske uddannelsesforsker B. Macfarlane har (Macfarlane 2017) beskrevet hvordan nye undervisnings- og evalueringsformer, promoveret med baggrund i "student engagement"-bevægelsen, har bidraget til, at de studerendes akademiske frihed er kommet under pres. Akademisk frihed indebærer:

... that university students should not have things imposed on them that they do not want. Instead there should be a right to choose. This would include students being allowed to judge for themselves whether attendance at lectures and other classes constitutes value for their time. Lectures should not be compulsory [..] Students should have the right to learn in ways that meet their needs and dispositions as persons. Here, I believe that the distinction between 'passive' as opposed to 'active' learning has become an over-simplified dualism that has led to the vilification of students who prefer to study in an undemonstrative manner [..] Student engagement policies and practices promote 'active' learning as an essential means of evidencing learning. Yet, relying on observation is a crude means of understanding the complexity of how students learn and engage. [..] Student must expend their energies being compliant and potentially fake certain prescribed attitudes or values. Such demands have nothing to do with the core purpose of a real higher education, which should be about learning and interrogating claims to knowledge and truth in an environment that promotes freedom and personal autonomy. (Macfarlane 2017, s. xiii-xiv).

Det er således ifølge Macfarlane især, når "studenteraktivitet" forveksles med læring, at de studerendes autonomi og akademiske frihed indskrænkes. Med henvisning til Sartres analyse af den uautentiske studerende, der har så travlt med at spille rollen som aktivt lyttende, at han helt glemmer at høre efter (Sartre 1956, s.60), introducerer Macfarlane begrebet "performativitet" (eng. "performativity") og benytter det til at benævne forvekslingen af aktivitet og læring.

Macfarlane diskuterer tre forskellige udartninger af fænomenet:

- Kropslig performativitet: F.eks. bedømmelseskrav baseret på tilstedeværelse - enten i form af simpel registrering af tilstedeværelse, men også f.eks., hvor tilstedeværelse en vis procentdel af undervisningen udgør indstillingsgrundlag for eksaminationen. Andre former for mere indirekte tilstedeværelseskrav er løbende tests i klasseundervisningen, der evt. kan udgøre en vis procentsats af den samlede karakter.

- Deltagelsesperformativitet: Den tvungne deltagelse i gruppearbejder er et problem, både som led i klasseundervisningen (med f.eks. peer assessment) og projektarbejder. Særligt uretfærdigt opleves det, når gruppen gives en fælles karakter for et projekt uden hensyn til individuelle bidrag. Det samme gælder løbende krav om deltagelse, f.eks. i diskussionsfora, hvilket fører til en udpræget bedømmelsestræthed hos mange, og at overfladestrategier bliver et rationelt valg for de studerende.

- Følelsesmassig performativitet: Macfarlane kritiserer også den måde, studerende forventes at underkaste sig de forskellige værdier, universitetet inkorporerer i sine strategidokumenter, og som finder vej til undervisningen. "Students should be free to learn without 
the requirement that they need to demonstrate emotional compliance with politically fashionable ideas or theories." (Macfarlane, 2017, s. 102)

Sådanne performative krav står i følge Macfarlane i modsætning til respekten for de studerendes akademiske autonomi, og harmonerer dårligt med målsætningen om, at de studerende gennem universitetsuddannelsen skal agere som studerende, der 'vil' deres uddannelse og med selvindsigt forholder sig til egen læring.

For at undgå disse former for performativitet identificerer Macfarlane (2017, s. 109) fire rettigheder, som han mener, bør respekteres i videregående uddannelse. Det er retten til ikke at blive indoktrineret, retten til at voere tilbageholdende, retten til selv at voelge hvordan man vil loere, og retten til at blive stolet på og behandlet som et voksent menneske. Det er svært at erklære sig uenig i disse rettigheder, der understøtter vores tilgang til rammesætning og præmisser for udvikling af den studerendes autonomi og udfoldelse af autenticitet.

Macfarlane ser såvel undervisnings- som evalueringsformer som trusler mod de studerendes rettigheder, men de eksempler på performativitet, han giver er næsten udelukkende knyttet til de evalueringsformer - specifikt summative evalueringer - der anvendes. Ofte er det igennem de summative evalueringer, at underviseren stiller specifikke krav til den studerendes performativitet, inklusiv løbende summativ bedømmelse såsom tilstedeværelseskrav.

Hvis vi som undervisere skal respektere de studerendes autonomi (og de rettigheder Macfarlane beskriver), kræver det derfor en nøje gennemtænkning af de evalueringsformer og kontrolmekanismer, vi bringer i anvendelse i forhold til de studerende. Yderligere kræver det, at vi ikke laver den fejlslutning at forveksle aktivitet med læring. Det er netop i forhold til denne 'performative fejlslutning', at en central faldgrube i anvendelsen af learning analytics åbner sig, og det er det, vi vil drøfte i det følgende.

\section{Learning analytics - muligheder og faldgruber}

Statistiske analyser af store datasæt bruges i stigende grad til beslutningsstøtte i diverse områder af samfundslivet, herunder i uddannelsessystemet, hvor den nye brug af data bliver markedsført under samlebetegnelsen learning analytics. Der findes ikke en autoritativ definition af begrebet 'learning analytics', men i oplægget til konferencen $1^{\text {st }}$ International Conference on Learning Analytics and Knowledge, der blev afholdt i 2011, definerede man begrebet som "the measurement, collection, analysis and reporting of data about learners and their contexts, for purposes of understanding and optimizing learning and environments in which it occurs" (LAK11, 2011). Denne definition er efterhånden blevet knæsat, og en variant af den er bl.a. at finde i princippapiret for det nyligt etableret Netværk for Learning Analytics, der er nedsat af Danmarks Akkrediteringsinstitution (Danske Learning Analytics Netværk, 2017). Som bredden i definitionen angiver, er der flere væsensforskellige målsætninger, der kan forfølges inden for rammen af learning analytics.

Papamitsiou og Economides (2014) identificerer seks forskellige overordnede mål i den hidtidige forskning, der er blevet udført inden for rammen af learning analytics, nemlig:

1) Modellering af studenteradfærd, specielt forudsigelse af studerendes læringsstratgier.

2) Forudsigelse af performance (f.eks. afsluttende karakterer). 
3) Feedback til undervisere og studerende om den studerendes performance f.eks. gennem webinterfaces der sammenfatter information om studenterpopulationen eller den enkelte studerende.

4) Forudsigelse af fastholdelse og frafald (hvor man blandt andet på baggrund af aktivitet på undervisningsplatformen og andre parametre om de studerende forudsiger risiko for frafald).

5) Effekten af forskellige former for feedback, $\mathrm{fx}$ via digitale medier.

6) Anbefaling af resurser baseret på sammenlignelighed med grupper af brugere.

Hvis den analyse er korrekt, har forskningen i learning analytics således hidtil haft fokus på udvikling af systemer eller institutionelle strategier frem for at have et mere direkte fokus på de studerendes læring.

Ud over at have forskellige mål, kan de konkrete learning analytics-analyser tage afsæt i forskellige typer af data om de studerende. Det kan enten være baggrundsdata (som fx adgangsgivende karakter, faglig profil, social baggrund eller etnicitet), data, de studerende har genereret på den online undervisningsplatform, de bruger ( $\mathrm{fx}$ antal opgavebesvarelser, tid brugt på opgavebesvarelser på undervisningsplatformen, resultat af quizzer), antal bidrag i et forum ( $f x$ sociale medier eller universitetets undervisningsplatform), eller data indhøstet specielt til lejligheden ( $f x$ registrering af de studerendes tilstedeværelse ved hjælp af deres nøglekort eller wifi-login, webcam-optagelser af de studerende mv.) (Sclater et al. 2016, s. 17; Papamitsiou og Economides 2014).

Der vil typisk være tale om maskinelt indhøstede data, og disse datasæt kan være uoverskueligt store. Learning analytics rummer derfor ofte et element af Big Data-analyse, dvs. statistisk modellering, hvor man søger efter sammenhængen mellem forskellige faktorer med henblik på at lave en matematisk model - en algoritme -så man fremover med en vis sandsynlighed vil kunne forudsige en faktor ud fra viden om de andre. Det epistemiske mål for Big Data-analyser er dermed proediktion og ikke en forståelse af den bagvedliggende kausalitet (se fx Mayer-Schönberger \& Cukier 2013).

Learning analytics kan dog langt fra altid identificeres med Big Data-analyse i denne rendyrkede forstand. Learning analytics betegner i højere grad brugen og kontekstualiseringen af resultater opnået ved analyser af store datasæt.

Som et konkret dansk eksempel på anvendelse af learning analytics udviklede en datalogistuderende fra Københavns Universitet i sit speciale en algoritme, der kunne udpege frafaldstruede gymnasieelever, dvs. studerende, der vil falde ud af deres uddannelse inden for de næste tre måneder. Algoritmen blev til ved hjælp af en machine learning-process, hvor statistiske sammenhænge mellem frafald og 17 forskellige faktorer, herunder fraværd, klassestørrelse, skolens størrelse, køn, etnicitet, gennemsnitsindkomst i elevens postnummerområde mv. blev analyseret. Algoritmen blev trænet på et datasæt fra Lectio, den undervisningsplatform der anvendes på de fleste danske gymnasier. Efter endt træning havde algoritmen en træfsikkerhed på godt $93 \%$, dvs. hvis man fodrede algoritmen med data om en elevs fraværd, klassestørrelse, køn, etnicitet mv., ville den - på historiske data - med $93 \%$ sikkerhed kunne afgøre, om den pågældende elev ville forlade sin uddannelse inden for de næste tre måneder (Şara 2014; Şara et al. 2015; Møllerhøj 2015). Pointen med denne nye viden er, at den kan bruges konstruktivt i form af, at underviserne kan tage didaktiske be- 
slutninger, der konkret kan understøtte elever, der identificeres som 'i farezone' uden at stigmatisere dem. Det er dog klart, at man ikke kan vide om systemet i praksis vil blive brugt på den måde. Den nye viden kan lige så vel blive brugt til at frasortere de frafaldstruede elever hurtigt og effektivt. Tilsvarende er der en klar usikkerhed forbundet med brugen af en algoritme, der udelukkende på baggrund af en statistisk analyse af fortidige data giver prædiktioner om fremtiden. Ændringer i de overordnede rammer for fravær, undervisningsplatformens design eller i måden, underviserne bruger den på, kan føre til adfærdsændringer, der gør algoritmens prædiktioner upålidelige (se fx Lazer et al 2014 for et konkret eksempel på fejlslagen brug af Big Data samt Papamitsiou og Economides 2014 for en mere udfoldet SWOT-analyse). Det er med andre ord ikke problemløst at implementere et system som den pågældende algoritme til frafaldsanalyse. Man kan ikke være sikker på, at de positive konsekvenser, man forestiller sig systemet vil have, materialiserer sig af sig selv.

Som et eksempel på en mere overordnet vision for, hvordan learning analytics kan inddrages i en uddannelse, tilbyder den halvoffentlige Britiske organisation Jisc en samlet infrastruktur, der i en rapport beskrives som følgende:

[D]ata from sources such as the VLE [virtual learning environment], the SIS [Student Information System], library systems and students' own 'self-declared' data feed into the learning analytics warehouse. At the heart of the architecture is the learning analytics processor where predictive analytics are carried out, and lead to action coordinated by the alert and intervention system. Visualisations of the analytics for staff are available in a series of dashboards, and a student app allows learners to view their own data and compare it with others.

The student app provides students with data on how their engagement and attainment compare with those of other students, enabling them to plan and set targets for their learning and to receive positive reinforcement through the app when they meet these targets. Meanwhile a student consent service helps to ensure privacy by enabling students to give their permissions for data capture and use. (Sclater et al 2016, p. 18)

Forfatterne forestiller sig, at denne tankegang kan udmønte sig i en praksis, hvor kun den studerende har adgang til learning analytics-generede informationer om sig selv via dashboards, og at det er den studerende, der vælger, hvornår der er behov for at kontakte underviser eller fx tilknyttede mentorer. Hermed aktualiseres den studerendes mulighed for 'informeret selvstyre' og dermed også potentielt en styrkelse af den studerendes autonomi.

Learning analytics systemers overordnede mål er, jævnfør definitionen ovenfor, at undersøge sammenhænge mellem dele af de studerendes adfærd og målbare aspekter af og for deres læring. Systemer af den type kan rumme mulighed for formativ feedback til studerende og kan gøre det muligt at pege på specifikke områder i læringsmiljøet, der kræver tilpasning eller revision. Anvendt på den måde kan learning analytics være et nyttigt redskab for både undervisere og studerende. Det er dog også klart, at learning analytics samtidig rummer en trussel mod de studerendes læringsfrihed og mulighed for at optræde autentisk, særligt når learning analytics kobles til adfærdskontrol.

Det er et velkendt fænomen, at modeller af menneskelig adfærd ikke blot beskriver adfærden, men også ændrer den, særligt når fænomenet kobles til kontrol af adfærden. Den britiske økonom Charles Goodhart beskrev (i en kritik af makroøkonomiske modeller) problemet således: 
any observed statistical regularity will tend to collapse once pressure is placed upon it for control purposes(Goodhart 1984, s. 96).

Observationen er gået over i litteraturen som 'Goodharts lov', om end den typisk formuleres i den mere generelle form:

When a measure becomes a target, it ceases to be a good measure (se fx Strathern 1997, s. 308; Elton 2004).

Goodharts lov udgør et væsentligt epistemologisk problem, som enhver seriøs brug af learning analytics bør forholde sig til. Vi vil her argumentere for, at det også udgør et didaktisk og pædagogisk problem. Studerende agerer strategisk, og i det omfang de føler, at en learning analytics-algoritme belønner visse adfærdsmønstre, mens den straffer andre, er det ikke utænkeligt, at de vil begynde at imitere det adfærdsmønster, algoritmen forbinder med akademisk succes. 'Straf' skal her forstås bredt som inkluderende sanktioner fx i form af dårligere karakterer i et fag, indkaldelse til samtaler med studievejleder, booking af uønskede møder med en mentor, meddelelser om, at man klarer sig relativt dårligere end ens studiekammerater eller pop-up beskeder om, at man bedømt på sine ansigtstræk virker ukoncentreret (se fx programmet Nestor fra LCA Learning http://ai.Icalearning.net/). Sagt mere direkte: Hvis en learning analytics-algoritme belønner adfærdstræk som tilstedeværelse, opgaveaflevering og rettet opmærksomhed, risikerer man at strategisk orienterede studerende møder op til undervisningen uden at følge med, afleverer opgaver uden indhold og lærer at se fokuserede og koncentrerede ud, når det er opportunt. Med andre ord fører Goodharts lov i en undervisningsmæssig sammenhæng til uautentisk adfærd og (kropslig) performativitet; man spiller, at man er en god studerende, hvad enten man er det eller ej.

For at illustrere vores pointe og for at udstikke en retning for en positiv brug af learning analytics vil vi se lidt nærmere på hvordan to af de adfærdsfaktorer, der benyttes i learning analytics systemer, nemlig fysisk tilstedeværelse og registrering af løbende afleverings-opgaver, kan benyttes hhv. summativt og formativt i undervisningen. De følgende eksempler inddrager et learning analytics perspektiv, hvor der er tale om mindre datasæt.

Som det første vil vi se på to eksempler på brugen af clickers. På et etikkursus med 250 studerende på Dartmouth College brugte man clickersvar til at sikre de studerendes tilstedeværelse. Imidlertid konstaterede underviserne at de fik langt flere clicker svar end antallet af deltagere i auditoriet; det viste sig, at mange studerende svarede for hinanden, og 64 studerende blev efterfølgende anklaget for snyd (Wolfe, 2015). Clickerne blev her anvendt til en summativ evaluering, og strategiske studerende fandt en (ret radikal) måde at performe det adfærdstræk, der blev belønnet, gennem en uautentisk adfærd. Som et tilsvarende dansk eksempel har man på fakulteterne Arts og Aarhus BSS ved AU siden 2018 brugt programmet "Qwickly" til at registrere de studerendes fravær på kurser, hvor tilstedeværelse er en del af bedømmelsen. Med programmet skal de studerende via deres telefon registrere sig ved at indtaste en bestemt pin-kode som frigives ved undervisningens start, og som kun er åben f.eks. i et par minutter. Bekymringen her er, selvsagt, at studerende simpelthen sender koden til andre og på den måde performer deres tilstedeværelse (Brems, 2018).

At anvende clickers (eller telefoner) til kontrol og summativ evaluering, er nok fortsat ret usædvanligt - de bruges formodentlig oftere rent formativt og til løbende tilpasning af læringsmiljøet. I et casestudie, hvor de studerende brugte clickers, som kunne spores tilbage til hver enkelt studerende, oplevede de studerende det som en fordel, at underviseren vidste, 
hvem der havde svaret hvad i de enkelte clicker-sessioner $\mathrm{i}$ forbindelse med holdundervisningen (Mathiasen, 2015). Underviser havde meldt ud, at han kun ville bruge de indhøstede data til at tilpasse undervisningen og til at vejlede den enkelte studerende. Eksempelvis kunne han hjælpe studerende, der havde svaret forkert på spørgsmål inden for 'dagens tema', ved i pausen at give dem råd om tekstlæsning og opgaveløsning, så deres læringsaktiviteter om 'dagens tema' blev konkretiseret og gjort operationaliserbare. Det var op til de studerende, om de fulgte undervisers råd. Her var der konsensus mellem underviser og studerende om, at clickersvar skulle bruges læringsunderstøttende. Spørgsmålet om anonymitet/ikke anonymitet var ikke problematisk. I virkeligheden var den største udfordring for underviseren, at vedkommende havde en ganske stor datamængde, at forholde sig til. De studerende gav udtryk for, at de forventede og ønskede, at underviser brugte de indhøstede data. Underviser har i denne case valgt en rent formativ tilgang til de studerendes clickersvar, og forventningsafstemningen mellem studerende og underviser var, at underviser brugte de studerendes clickersvar i en konstruktiv fortløbende proces med blik for de studerendes autonomi og autenticitet, og svarene indgår ikke i summativ bedømmelse. I et sådant design giver det ikke mening at svare for andre.

Som et andet konkret eksempel, ønskede en underviser på et dansk universitet at styrke læringsudbyttet ved at få flere studerende til at aflevere de løbende afleveringer (personlig kommunikation, 2018). På kurset indgik ugentlige afleveringsopgaver, som de studerende frivilligt kunne vælge at aflevere og få feedback på. Kurset afsluttedes med en skriftlig stedprøve. Statistikken fra tidligere hold viste, at omkring $90 \%$ af de studerende, der afleverede mere end 4 af de frivillige løbende afleveringsopgaver bestod eksamen, mens kun en tredjedel af dem, der afleverede færre opgaver bestod. For at få flere studerende til at aflevere opgaverne, gjorde man opgaverne obligatoriske og lod bedømmelsen af de bedste af afleveringerne udgøre $40 \%$ af den endelige karakter - et umiddelbart nærliggende tiltag. Ænndringen betød, at flere studerende afleverede opgaverne, men også at kvaliteten af de afleverede opgaver steg markant. Mange studerende præsterede væsentligt bedre i de løbende opgaver end i stedprøven (et fænomen også beskrevet i Bjælde et al. 2017). Færre studerende afleverede opgaver, hvor der var behov for at give meget formativ feedback, og underviseren måtte også konstatere, at tidligere studenteropgaver inklusive lærerfeedback var uploadet til internettet. Den læringsmæssige funktion, som hjemmeopgaverne havde tidligere, var, i hvert fald for nogle studerendes vedkommende, blevet afløst af et fokus på at leve op til en summativ bedømmelse - men uden at give det relevante læringsudbytte, der kunne hjælpe dem til en god karakter i stedprøven.

Med andre formater, f.eks. temaopgaveformatet (Winsløw og Grønbæk, 2004) eller portfoliobedømmelse, er der gode erfaringer med at få de studerende til at aflevere løbende opgaver. I temaopgaveformatet arbejder de studerende (typisk) gruppevis løbende med opgaver som de får feedback på, men som ikke bedømmes summativt. Den summative bedømmelse er alene ved en mundtlig eksamen hvor deltagerne "trækker" et af de i kurset behandlede temaer til fremlæggelse. I dette format er der mindre tilskyndelse til uautentisk adfærd, og der er endda tilskyndelse til at arbejde videre med opgaverne, efter de studerende har fået feedback på deres besvarelser, da opgaverne fungerer som udgangspunkt for den mundtlige fremlæggelse.

Eksemplerne ovenfor er learning analytics i det små, men illustrerer, hvordan aggregeret måling af ydre adfærdsparametre i eksisterende undervisningsformer kan bruges på måder, der enten styrker eller svækker de studerendes frihed og mulighed for at optræde autentisk. 
Lignende historier kan fortælles om brugen af andre adfærdsparametre til brug i en summativ evaluering, såsom tilstedeværelse på online undervisningsplatforme (Gathuri et al, 2014), optælling af antal indlæg i online diskussioner (Andersen, 2011) mv. Fordelen ved at se på relativt små eksempler er, at man kan få en fornemmelse for de mekanismer, der er i spil, hvilket kan være vanskeligere for større og mere integrerede systemer. Når man designer learning analytics systemer, eller som underviser inddrager dem i sin undervisning, er det centralt, at man tager ved lære af denne type erfaringer med evalueringsformer; hvis man anvender learning analytics til summativ kontrol, risikerer man at fremme uautentisk adfærd hos de studerende. Eksemplerne viser også, hvordan ret små forskelle i designet af undervisningen i forhold til forholdet mellem formativ og summativ evaluering kan føre til store ændringer i studenternes adfærd.

\section{Platforme og nudging}

Et særskilt problem i denne forbindelse er, at nogle undervisningsplatforme synes at have en stærk præference for kvantitativ bedømmelse af studerendes arbejder, eller i hvert fald tilbyder de denne funktion. Et karakteristisk eksempel på dette er, at systemernes defaultindstillinger, når man skal oprette en opgaveaflevering, en quiz, eller en test, er at denne skal point- eller karaktergives (se eksempel i figur 1 ).

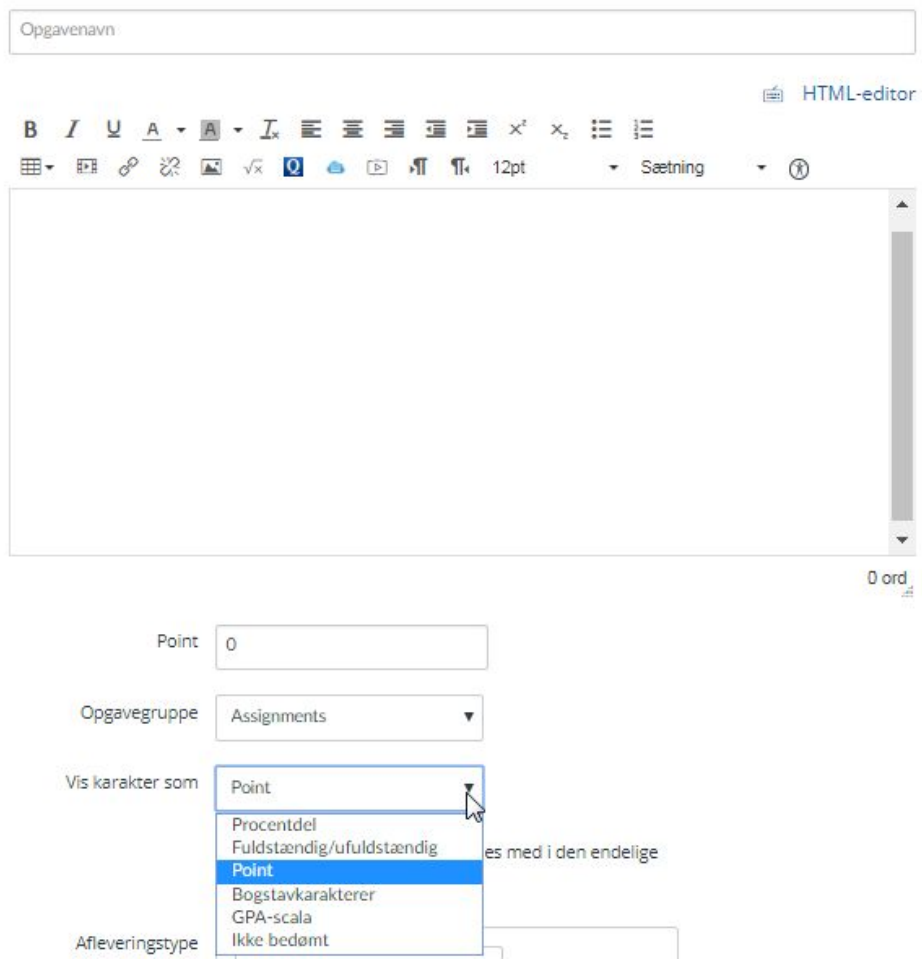

Figur 1. Eksempel på oprettelse af en opgave i systemet Canvas (som anvendes på Københavns Universitet). Default-instillingen er pointgiving. Noget tilsvarende gør sig gældende i Blackboard (som anvendes af AU og SDU) og Moodle (der anvendes af AAU og RUC).

Thaler og Sunstein, ophavsmændende til begrebet nudge, har blandt andet peget på, hvordan default indstillinger i online skabeloner har afgørende indflydelse på, hvilke valg, de, der udfylder dem, træffer - også selvom disse valg ikke nødvendigvis er i personernes egne interesser (Thaler \& Sunstein, 2008, kapitel 1; se også Hansen \& Jespersen, 2003). Det er derfor 
ønskværdigt, at de defaultindstillinger, der af systemet indstilles i en undervisningsplatform også er dem, der fører til det det bedste udkomme - dvs. bidrager bedst til de studerendes mulighedsbetingelser for at lære og udvikle sig i samklang med det, studieordningerne foreskriver.

I lyset af den ovenstående diskussion om summativ og formativ bedømmelse, synes det tvivlsomt, om det er tilfældet. Thaler og Sunstein beskriver et nudge som en konstrueret valgsituation, hvor det, som er det rationelle valg, bliver det nemme valg - og hvor folk stadig har frihed til træffe autonome beslutninger. Universiteternes undervisningsplatforme giver nok underviserne valgmuligheder til at træffe egne valg, men gør det ikke let at træffe valg, der er rationelle i den forstand, at de understøtter de studerendes autonomi og mulighed for at optræde autentisk. Dette forstærkes af, at underviserne gennem systemets anvendelse af learning analytics udsættes for et væld af information, herunder normative domme om de enkelte studerende, der som regel siger ganske lidt eller intet om de studerendes faglige udbytte og selvstændige arbejde med det faglige indhold (se figur 2).

㷉

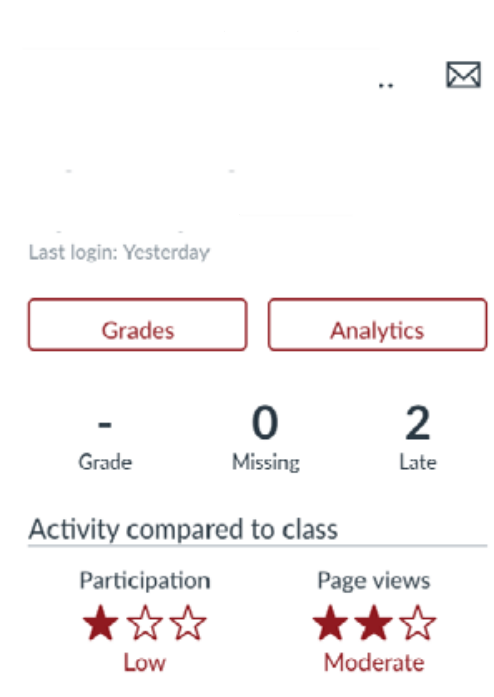

[studerendes billede

og navn udeladt]

Figur 2. Anonymiseret opslag på studerende fra undervisningsplatformen Canvas. Her tildeles de studerende automatisk stjerner på baggrund af sammenligning af aktivitet med øvrige deltagere på kurset, baseret på en uigennemskuelig algoritme for deltagelse og sidevisninger. Ved at klikke på "analytics" kan man som underviser følge den enkelte studerendes sidevisninger, uploads og øvrige adfærd på undervisningsplatformen.

\section{Diskussion og konklusion}

I lyset af Macfarlanes kritik er det nærliggende også at udstrække nudge-tankegangen til forholdet mellem undervisere og studerende, og at stille spørgsmålet: Hvordan kan vi tilrettelægge undervisningen på måder, som gør det let for de studerende at træffe rationelle valg (ift. deres læring), uden at deres akademiske frihed indskrænkes? Her har learning analytics en vigtig rolle at spille i forhold til at gøre undervisere og uddannelsesplanlæggere klogere på, hvori de rationelle valg består. For at vende tilbage til eksemplet med afleveringsopgaver, kan learning analytics være med til at fortælle os, om et autentisk arbejde med opgaverne er et rationelt valg for de studerende, og hvis det er tilfældet, kan man bruge den viden til at designe læringssituationerne derefter. Mere generelt kan undervisere bruge aggregerede data om tidligere studerendes adfærd til at designe eller re-designe undervisningsforløb, 
men de skal være påpasselige med at anvende disse data til adfærdsregulering eller yderligere kontrol af de studerende gennem summativ bedømmelse eller profilering, da dette vil indebære en indskrænkning af de studerendes autonomi og en risiko for uautentisk adfærd hos de studerende (Goodharts lov).

Learning analytics vil muligvis også kunne bruges til at oplyse den studerende om egne fremskridt og muligheder, så den studerende kan justere sine læringsstrategier og eventuelt efter egen vurdering af behov - kontakte undervisere, vejledere, uddannelsesledere, studievejledere, psykologer og andre, der kan stille op som resursepersoner. Det er dog centralt, at intentionen med at indsamle og analysere data ikke er kontrol og overvågning, men tværtimod er at give de studerende redskaber, der gør det lettere for dem at udøve deres autonomi gennem kvalificerede valg. Det er desuden væsentligt, at de studerende oplyses om, hvordan eventuelle analyser er genereret.

Begge disse tilgange til anvendelsen af learning analytics understøtter udviklingen af akademisk dannelse og dermed den studerendes autonomi til at handle på et informeret grundlag. Med andre ord, bør den væsentligste anvendelse af learning analytics være den formative anvendelse i forhold til styrkelsen af de studerendes læring og udvikling, fremfor kontrol og adfærdsregulering, selvom også formative vurderinger kan invitere til, at de studerende vælger en anden adfærd end den, der var intenderet af underviser og det rammesatte læringsmiljø.

Med spørgsmålet, hvordan kan undervisere på landets universiteter fastholde og bidrage til at udvikle studerendes autonomi og autenticitet $\mathrm{i}$ en uddannelsesmæssig virkelighed, hvor monitorering, kontrol og bedømmelse spiller en stadig større rolle, har vi drøftet både de muligheder og de faldgruber, learning analytics tilbyder.

Vi har valgt at undersøge learning analytics gennem en optik, der fokuserer meget entydigt på de studerendes mulighed for at udøve autonomi og autenticitet, og dermed frihed til at udvikle akademisk dannelse. Der er selvfølgelig andre hensyn at tage i universitetsundervisningen, f.eks. hensynet til gennemførselstider og frafaldsprocenter som jo er afgørende for institutionernes økonomi. Hensynet til de studerendes læringsfrihed kan ikke stå alene, men må i praksis vejes op mod andre hensyn. Der kan imidlertid være god grund til at læringsfriheden ikke glemmes, når vi diskuterer hvordan learning analytics-redskaber skal designes og implementeres. Læringsfriheden har en centrale rolle (som betonet af Macfarlane), hvis universiteterne skal nå deres målsætning om at uddanne kritisk tænkende, selvstændige individer. Den må derfor medtænkes, når vi overvejer, hvordan og til hvad vi vil anvende learning analytics. Det danske netværk for learning analytics har udarbejdet et princippapir for, hvad learning analytics kan bruges til - og her peges især på den formative understøttelse af læringen. Der peges også på nogle få anbefalinger til hvad learning analytics ikke bør bruges til, og hér nævnes specifikt, at learning analytics ikke bør anvendes til at "foretage en faglig bedømmelse af de studerende eller underviserne" (Netværk for learning analytics, 2017). Vi kan fuldt ud tilslutte os disse anbefalinger, set i lyset af de argumenter, vi har udfoldet i denne artikel.

Endelig bør det bemærkes, at denne artikels fokus på den enkelte studerendes autonomi og autenticitet samtidig fører til, at læringens sociale dimension underbetones. Den ensidige betoning af de studerendes autonomi hos Macfarlane gør spørgsmålet om læring til et spørgsmål om individuel tilegnelse, men giver ikke plads til at tillægge de studerende et ansvar for etableringen, vedligeholdelsen og udviklingen af læringsmiljøet. De studerende be- 
tragtes som "forbrugere" af undervisningsmiljøer designet af undervisere. Det er et utilstrækkeligt billede. Gode læringsmiljøer udvikles jo ikke mindst gennem de sociale relationer mellem undervisere og studerende, og de studerende imellem. De rettigheder, som Macfarlane relevant mener, de studerende bør have, kommer derfor også med faglige forpligtelser over for de øvrige studerende og underviseren. Gode læringsmiljøer formår at balancere studerendes rettigheder og forpligtelser i forhold til hinanden på en måde, så studerende kan agere autentisk i deres læring. Hvordan learning analytics spiller ind i de studerendes sociale forpligtelser i læringsmiljøet, er et beslægtet spørgsmål til spørgsmålet om påvirkning af studerendes autonomi og autenticitet, der i høj grad også er værd at undersøge.

\section{Referencer}

Abrahamsen, S. (2017). Undervisere råber op: Fremdriftsreformen dræber de studerendes kreativitet. Information, 15. april. URL: https://www.information.dk/indland/2017/04/undervisere-raaberfremdriftsreformen-draeber-studerendes-kreativitet

Andersen, L.T. (2011). Constructive alignment of the E-learning Course Introduction to Dairy Technology. I F.V. Christiansen, L. Ulriksen, C. Rump, J. Sølberg \& H.W. Hansen (red.). (2011). Improving University Science Teaching and Learning 4(1-2), kap. 6.

Angwin, J. Larson, S. M. og Kirchner, L. (2016). Machine Bias. ProPublica. URL: https://www.propublica.org/article/machine-biasrisk-assessments-in-criminalsentencing (besøgt 1/8/2018).

Bjælde, O.E., Jørgensen, T.H. \& Lindberg. (2017) Continous assessment in higher education in Denmark: Early experiences from two science courses. Dansk Universitetspaedagogisk Tidsskrift 12(23), 1-19.

Brems, M. (2018) Nu skal studerendes fremmøde registreres digitalt. Omnibus, 6/3 2018. URL: http://omnibus.au.dk/arkiv/vis/artikel/nu-skal-studerendes-fremmoede-registreresdigitalt/

Danske Learning Analytics Netværk (2017). URL: http://akkr.dk/om/learning-analyticsnetvaerk/og http://akkr.dk/wp-content/filer/akkr/Principper-for-Learning-analytics2.pdf)

Davis, S., Drinan, Patrick F, Bertram Gallant, Tricia, \& Wiley InterScience. (2009). Cheating in school, what we know and what we can do. Chichester, U.K. Malden, MA: WileyBlackwell.

Ejsing, J. (2016). Søren Pind efterlyser karakter for "den helt exceptionelle præstation". Berlingske Tidende, 20. december.

Eika, B., Andersen, H.L., Hermann, S., Øhrgaard, P., Binning, P., Andersen, N.O., Willerslev, R. Inspirationsgruppen om nyt filosofikum: Afrapportering til uddannelses- og forskningsministeren. Uddannelses- og forskningsministeriet. URL: https://ufm.dk/publikationer

Elton, L. (2004). Goodhart's law and Performance Indicators in Higher Education. Evaluation and Research in Education 18(1-2). 
Elling, R. C. \& Groes, C. (2015). Manifest for det frie universitet. Politiken, 29. april. URL: https://politiken.dk/debat/art5575058/Manifest-for-det-frie-universitet

Mathiasen, H. (2015). Digital Voting Systems and Communication in Classroom Lectures - an empirical study based around physics teaching at bachelor level at two Danish universities. Journal of Interactive Media in Education.

Gathuri, J.W., Luvanda, A., Matende, S \& Kamundi, S. (2014). Impersonation Challenges Associated with E-assessment of University Students. Journal of Information Engineering and Applications 4(7).

Goodhart, Charles (1984). Monetary theory and practice, the UK experience. London: Macmillan.

Hansen, P.G. \& Jespersen, A.M. (2013). Nudge and the Manipulation of Choice. A Framework for the Responsible Use of Nudge Approach to Behaviour Change in Public Policy. European Journal of Risk Regulation, 2013(1).

Helmholtz, H. v. (1877). Om den akademiske frihed ved de tyske universiteter. I J.E. Kristensen,K. Elstrøm, J.V. Nielsen, M. Pedersen, B.V. Sørensen \& H. Sørensen (red.) (2007). Idéer om et universitet. Aarhus Universitetsforlag.

Humboldt, W. v. (1810). Om den indre og ydre organisation af de højere videnskabelige læreanstalter i Berlin. I J. E. Kristensen, K. Elstrøm, J. V. Nielsen, M. Pedersen, B. V. Sørensen \& H. Sørensen (red.). (2007). Ideer om et universitet. Aarhus Universitetsforlag.

Kjærgaard, P.C. \& Kristensen, J.E. (2003). Universitetets idéhistorie. I H. Fink, P.C. Kjærsgaard, H. Kragh \& J.E. Kristensen (red.). (2003). Universitet og videnskab. Hans Reitzels forlag.

LAK11. (2011). 1st International Conference on Learning Analytics and Knowledge. URL: https://tekri.athabascau.ca/analytics/

Lazer, D. Kennedy, R. King, G., Vespignani, A. (2014). The Parable of Google Flu: Traps in Big Data Analysis. Science 343(6176), 1203-5.

Lund, K. \& Pedersen, P. A (2015). Danmark har ikke kun brug for 12-tals piger og drenge. Politiken, 29. august

Macfarlane, B. (2017). Freedom to Learn. The threat to student academic freedom and why it needs to be reclaimed. Society for Research into Higher Education. UK: Routledge.

Mayer-Schönberger, V., \& Cukier, Kenneth. (2013). Big data, a revolution that will transform how we live, work, and think. London: John Murray

Mittelstadt, B.D. og Floridi, L. (2016). The Ethics of Big Data: Current and Foreseeable Issues in Biomedical Contexts. Science and Engineering Ethics 22:303-341.

Møllerhøj, J. (2015). It-system til varsel af elevfrafald blev øjeblikkeligt standset af gymnasierne, Version2, 17. august 2015. Online tekst tilgængelig på: https://www.version2.dk/artikel/noejagtig-frafalds-algoritme-blankt-afvist-i-udbredtgymnasie-it-320922 (sidst tilgået 27/2 2019).

Papamitsiou, Z. og Economides, A.A. (2014). Learning Analytics and Educational Data Mining in Practice: A Systematic Literature Review of Empirical Evidence, Journal of Educational Technology \& Society, 17(4): 49-64. 
Şara, N-B. (2014): School Drop Out Prediction (master's thesis), Copenhagen: University of Copenhagen, Department of Computer Science.

Şara, N-B., Halland, R., Igel, C., \& Alstrup, S. (2015). High-school dropout prediction using machine learning: a Danish large-scale study. I M. Verleysen (red.), Proceedings. ESANN 2015: 23rd European Symposium on Artificial Neural Networks, Computational Intelligence and Machine Learning (pp. 319-324). i6doc.com.

Sartre, J-P. (1956). Being and nothingness: An essay on phenomenological ontology. New York: Philosophical Library.

Sclater, N., Peasgood, A., Mullan, J. (2016). Learning Analytics in Higher Education. A review of UK and international practice. Full report. Bristol: JISC. Online dokument tilgængelig på: https://www.jisc.ac.uk/reports/learning-analytics-in-higher-education

Strathern, M. (1997). 'Improving ratings': audit in the British University system.European Review, 5, pp 305-321 doi:10.1002/(SICI)1234-981X(199707)5:33.0.CO;2-4

Solberg, M. \& Hansen, F. T. (2015). On Academic Bildung in Higher Education - a Scandinavian Approach. I T. Fossland, H. Mathiasen \& M. Solberg: Academic Bildung in Net-based Higher Education. Moving beyond learning, Routledge Research in Higher Education, Routledge.

Thaler, R.H \& Sunstein, C. (2008). Nudge - Improving Decisions about Health, Wealth and Happiness. New Haven: Yale University Press.

Winsløw, C. \& Grønbæk, N. (2004) Temaopgaver - et format til fremme og evaluering af dybdelæring. Didaktips 4, Center for Naturfagenes didaktik. URL: https://www.ind.ku.dk/publikationer/didaktips/didaktips4/

Wolfe, R. (2015). Dartmouth: 64 students cheated. Valley News, 8. januar. URL: https://www.vnews.com/Archives/2015/01/DartmouthCheatSanctions-rw-vn-010815 